\title{
GOOD MANURE MANAGEMENT: CASE STUDY OF DAIRY FARM WITH LOOSE HOUSING SYSTEM
}

\author{
Roman Uvarov, Natalia Vasileva, Ekaterina Vorobyeva \\ Federal Scientific Agroengineering Centre VIM, Russia \\ rauvarov@gmail.com, vasileva0203@yandex.ru, ekaterina.vorobyeva@gmail.com
}

\begin{abstract}
One of the most important directions of economic development is improving the environmental safety of production. Farm manure is the factor, which has the greatest effect on the environmental sustainability of the local agroecosystem. The rational manure handling system reduces the negative impact on the environment. Application of sustainable nature management principles allows producing various types of useful products, for example, bedding for farm animals. Thereby, the economic costs of manure processing and the purchase of bedding materials drop, and the production profitability increases. Three manure-processing options, which are used to produce bedding from manure, were considered for a dairy farm with the cow stock of 100 head. Option 1 - solid-liquid manure separation, aerobic fermentation of the solid fraction in a drum bio-fermenter and longterm storing (maturing) of the liquid fraction. Option 2 - mixing the native manure with peat and the subsequent aerobic fermentation in a drum bio-fermenter. Option 3 - mixing the native manure with peat and the subsequent aerobic fermentation in a chamber bio-fermenter. According to the study results, Option 1 had the capital costs of $395914 \mathrm{EUR}$, the operational costs of $151302 \mathrm{EUR}$, the labour inputs of 0.45 man-hours $\cdot \mathrm{t}^{-1}$, and the payback period of 2.5 years. Options 2 and 3, requiring the addition of peat as a moisture absorber, showed higher capital costs (1 416571 EUR and 1030429 EUR, respectively), operating costs (457 305 EUR and 376922 EUR, respectively) and labour inputs (0.84 and 0.94 man-hours $\cdot \mathrm{t}^{-1}$, respectively), resulting in negative profitability. The choice of a rational manure-processing technology allows the farmers to reduce costs and to receive an additional profit.
\end{abstract}

Keywords: manure handling, bedding, solid-state fermentation, economic viability.

\section{Introduction}

The changes observed in various sectors of the economy in recent years also apply to agriculture. Intensification of farming, introduction of best available techniques (BAT), and transition to new livestock housing practices result in higher volumes of both main agricultural products - milk, meat, eggs, animal and poultry stock, and the associated waste - animal and poultry manure [1].

Many livestock enterprises do not have their owned agricultural land sufficient for the application of all manure produced. Therefore, they are forced to search for new, more efficient ways of manure processing and use. One such method is to produce manure-based bedding for farm animals. This technology was first tested in the 1970s on the farms located in the arid western regions of the United States of America.

Due to the high bacterial risks, additional processing steps were added to reduce the number of pathogens in the final product by increasing the processing temperature [2]. In the past few years this technology is gradually becoming more widespread in other countries as well [3-5]. This manure processing method allows improving the farm profitability through lower manure spreading costs and lower purchasing costs of bedding materials.

The study was focused on the economic feasibility of bedding production technologies in a functioning livestock enterprise.

\section{Materials and methods}

For the study purposes a dairy farm with 100 milking cows was selected for modelling the application of three technologies to produce manure-based bedding. Annually the selected farm produces around $800 \mathrm{t}$ of milk, $18 \mathrm{t}$ of meat in live weight and 16 head of young animals. The farm has 100 ha of agricultural land, located at a distance of $20 \mathrm{~km}$ and used for growing spring and winter cereals. The farm has a loose housing system of animals [6]. The annual peat bedding consumption is 40.2 tons. Under the loose housing systems of livestock the dry matter content in the native manure is $8 \%$. The manure output is $10.9 \mathrm{t} \cdot \mathrm{day}^{-1}$ or $3975.5 \mathrm{t} \cdot$ year $^{-1}$.

Three manure processing options were considered: 
- Solid-liquid separation of manure with subsequent aerobic fermentation of the solid fraction in a drum bio-fermenter and long-term storing (maturing) of the liquid fraction in the manure storage [7].

- Mixing of fresh manure with peat and subsequent aerobic fermentation in a drum biofermenter [8].

- Mixing of fresh manure with peat and subsequent aerobic fermentation in a chamber biofermenter [8].

The daily and annual manure output was calculated by the methodology elaborated and tested on 30 livestock and poultry farms [9]. The daily productivity of bio-fermenters depended on their dimension range substantiated by the guaranteed disinfection of the material [10-13].

It was assumed in calculations that no other components were to be added to have the aerobic fermentation process running for both the solid fraction of cattle manure and a mixture of cattle manure with peat [14].

The economic efficiency of the considered technologies was estimated by the standard methodology for determining the economic efficiency of technologies and agricultural machinery [15]. The prices of farm facilities, machines and equipment were relevant for December 2019.

\section{Results and discussion}

Option 1. Solid-liquid separation of manure, subsequent aerobic fermentation of the solid fraction in a drum bio-fermenter and long-term storing (maturing) of the liquid fraction in the manure storage.

Mechanical separators allow achieving up to $32 \%$ of dry matter content in the solid fraction of manure that is close to the optimal values to run the aerobic fermentation process [16].

The calculation results of the solid fraction after the manure separation are shown in Table 1.

Characteristics of separated solid fraction of manure produced on the selected farm

\begin{tabular}{|c|c|c|c|c|c|c|}
\hline \multirow{2}{*}{$\begin{array}{l}\text { Housing } \\
\text { system }\end{array}$} & \multicolumn{2}{|c|}{$\begin{array}{l}\text { Production of solid } \\
\text { fraction of manure }\end{array}$} & \multirow{2}{*}{$\begin{array}{c}\text { Dry } \\
\text { matter } \\
\text { content, } \\
\% \\
\end{array}$} & \multicolumn{2}{|c|}{$\begin{array}{c}\text { Dry matter amount, } \\
\text { kg } \cdot \text { day }^{-1}\end{array}$} & \multirow{2}{*}{$\begin{array}{l}\text { Required productivity of } \\
\text { a bio-fermenter with } \\
\text { due account for the type } \\
\text { and size range, } t \cdot \text { day }^{-1}\end{array}$} \\
\hline & $\mathrm{kg}$ day $^{-1}$ & $\mathrm{~m}^{3} \cdot \mathrm{day}^{-1}$ & & $\begin{array}{c}\text { In } \\
\text { manure }\end{array}$ & $\begin{array}{l}\text { In solid } \\
\text { fraction }\end{array}$ & \\
\hline $\begin{array}{l}\text { Loose } \\
\text { housing }\end{array}$ & 1907 & 2.9 & 32 & 872 & 610.4 & 2 \\
\hline
\end{tabular}

So that the processed manure can be used as a bedding material, it must meet the animal safety requirements. According to the experiments [13], manure is reliably disinfected from pathogenic microflora and parasites within 120 hours, or 5 days, after fermentation started in a cyclic (batch) mode and within 96 hours, or 4 days - in the continuous fermentation mode.

In view of this and the dimension range of bio-fermenters, it was found in our previous study that a bio-fermenter with the productivity of $2 \mathrm{t} \cdot \mathrm{day}^{-1}$ was needed to process the produced solid fraction of manure. At 0.75 filling degree, the working volume of the bio-fermenter's drum was $15.6 \mathrm{~m}^{3}$ that was sufficient for its continuous operation [10]. The bedding production rate was $1.43 \mathrm{t} \cdot \mathrm{day}^{-1}$, considering the mass and moisture loss.

The annual amount of bedding produced was 522.2 tons that was 482 tons more than the required amount. The surplus produced can be either sold to other farms or applied to the fields as an organic fertiliser.

Option 2. Mixing of native manure with peat and subsequent aerobic fermentation in a drum biofermenter.

For efficient aerobic fermentation the dry matter content in the fermented substrate should not be below $32 \%$. This can be achieved by adding a moisture absorbing material, peat, in particular, the required amount of which is determined by the formula (1):

$$
m_{P}=\frac{m_{M} \cdot\left(W_{M}-W_{S}\right)}{W_{S}-W_{P}}
$$


where $m_{P}$ - required mass of peat, $\mathrm{t}$;

$m_{M}$ - mass of native manure, $\mathrm{t}$;

$W_{M}$ - manure moisture content, $\%$;

$W_{S}-$ substrate moisture content, \%;

$W_{P}$ - peat moisture content, $\%$.

According to our calculations, 20.1 tons of peat with $45 \%$ dry matter content need to be added to 10.9 tons of native manure with $8 \%$ dry matter content produced on the farm daily to meet the above condition. The total mass of the substrate to be fermented will be 31 tons. To process this substrate the required equipment includes three bio-fermenters with the productivity of nine tons of the initial substrate per day with the working volume of $73.85 \mathrm{~m}^{3}$ and 1 bio-fermenter with the productivity of $6 \mathrm{t} \cdot \mathrm{day}^{-1}$ and the working volume of $49.2 \mathrm{~m}^{3}$.

Considering the mass and moisture loss during the fermentation process, the daily bedding produced will be $23.3 \mathrm{t}$, the annual $-8492.6 \mathrm{t}$. This amount significantly exceeds the farm's bedding requirement and sets the task of selling the surplus, as 8452.4 tons of processed material per year exceeds the allowable amount of organic fertiliser that can be applied to the own agricultural land.

Option 3. Mixing of native manure with peat and subsequent aerobic fermentation in a chamber bio-fermenter.

The initial data on the amount and humidity of the substrate to be fermented are the same as in Option 2. The annual amount of substrate is $11323.4 \mathrm{t}$. In general, the organic waste processing in chamber-type bio-fermenters has lower intensity compared to drum bio-fermenters resulting in smaller moisture loss and a longer fermentation process. With this fact in mind, the annual amount of bedding produced in these installations is $9058.7 \mathrm{t}$.

A distinctive feature of aerobic fermentation in chamber bio-fermenters is the cyclical (batch) process. It is impossible to remove a part of the ready product and to replenish partly the bio-fermenter every day. The production of bedding has more stringent sanitary, hygienic and moisture content requirements for the resulting product compared to the organic fertiliser production. Therefore, the duration of one bio-fermentation cycle was taken to be 8 days [17-19].

Depending on the filling degree of the biofermenter and the processed material (substrate) density, the capacity of one chamber bio-fermenter is 55-65 t of the initial substrate [16]. In our calculations, a capacity of $60 \mathrm{t}$ was adopted. Therefore, 6 chamber bio-fermenters are required to process the prepared substrate. The sequence diagram of filling the chamber bio-fermenter is shown in Table 2.

Table 2

Sequence diagram of filling the chamber bio-fermenter

\begin{tabular}{|c|c|c|c|c|c|c|c|c|c|c|c|c|}
\hline \multirow{2}{*}{ Biofermenter } & \multicolumn{10}{|c|}{ Fermentation cycle, day } \\
\cline { 2 - 16 } & 1 & 2 & 3 & 4 & 5 & 6 & 7 & 8 & 9 & 10 & 11 & 12 \\
\hline 1 & 31 & 29 & ssf & ssf & ssf & ssf & ssf & ssf & ssf & ssf & u & 31 \\
\hline 2 & $\mathrm{u}$ & 2 & 31 & 27 & ssf & ssf & ssf & ssf & ssf & ssf & ssf & ssf \\
\hline 3 & ssf & ssf & u & 4 & 31 & 25 & ssf & ssf & ssf & ssf & ssf & ssf \\
\hline 4 & ssf & ssf & ssf & ssf & u & 6 & 31 & 23 & ssf & ssf & ssf & ssf \\
\hline 5 & ssf & ssf & ssf & ssf & ssf & ssf & u & 8 & 31 & 21 & ssf & ssf \\
\hline 6 & ssf & ssf & ssf & ssf & ssf & ssf & ssf & ssf & u & 10 & 31 & ssf \\
\hline
\end{tabular}

31 - mass of substrate loaded in the fermenter, t;

ssf - solid-state fermentation;

$\mathrm{u}-$ unloading of the ready product.

The calculations of the economic efficiency of the considered manure processing technologies took into account the working volumes and areas of facilities, vehicle performance, production rates and recommended application rates of solid organic fertilisers.

Option 1. Solid-liquid separation of manure, subsequent aerobic fermentation of the solid fraction in a drum bio-fermenter and long term storing (maturing) of the liquid fraction in the manure storage require the following facilities and equipment: 
- Manure separation: one building with a volume of $9 \times 6 \times 3 \mathrm{~m}^{3}$ (11 570 EUR); one accumulation tank with a volume of $9 \times 4 \times 3 \mathrm{~m}^{3}$ (7 715 EUR); one screw separator of specified productivity (35 000 EUR); one manure pump (5 500 EUR); one mixer (7 700 EUR).

- Bedding production: one concrete pad of $4 \times 10 \mathrm{~m}^{2}$ in area (1 $\left.430 \mathrm{EUR}\right)$; one drum biofermenter with the productivity of $2 \mathrm{t} \cdot \mathrm{day}^{-1}$ (50 $000 \mathrm{EUR}$ ); one receiving hopper (5 $000 \mathrm{EUR}$ ); one loading device (2 000 EUR).

- Storing facilities for the bedding production components and ready products: two storages for the liquid fraction of a volume of $2000 \mathrm{~m}^{3}$ each (40 000 EUR); one concrete pad with a shelter of $16 \times 10 \mathrm{~m}^{2}$ in area (5 715 EUR).

- Transport facilities: one pipeline with a pump (7 850 EUR); one tractor of 2.0 drawbar category (35 715 EUR); one trailer with a 6 t capacity (12 140 EUR); one front-end loader with at least a $1.5 \mathrm{~m}^{3}$ bucket (42 850 EUR).

- Organic fertiliser application: one tractor of 2.0 drawbar category (35 715 EUR); one machine for solid fertiliser spreading with a 6 t capacity (14 285 EUR); one tractor of 3.0 drawbar category (45,700 EUR); one machine for liquid fertiliser application with an $11 \mathrm{t}$ capacity (30 000 EUR).

Option 2. Processing of manure mixed with peat in a drum bio-fermenter requires the following facilities and equipment:

- Bedding production: one concrete pad of $20 \times 15 \mathrm{~m}^{2}$ in area (10 $715 \mathrm{EUR}$ ); one drum biofermenter with the productivity of $6 \mathrm{t}^{-\mathrm{day}^{-1}}$ (121 $400 \mathrm{EUR}$ ); three drum bio-fermenters with the productivity of $9 \mathrm{t} \cdot \mathrm{day}^{-1}$ each (535 600 EUR); four receiving hoppers (20 $000 \mathrm{EUR}$ ); four loading devices (8 000 EUR).

- Storing facilities for the bedding production components and ready products: one concrete pad with a shelter to store a three-day supply of peat of $30 \times 12 \mathrm{~m}^{2}$ in area (12 850 EUR); one concrete pad with a shelter to store the ready bedding of $55 \times 48 \mathrm{~m}^{2}$ in area (94 280 EUR).

- Transport facilities: three tractors of 2.0 drawbar category (107 145 EUR); three trailers with a $6 \mathrm{t}$ capacity each (36430 EUR); two front-end loaders with at least $3 \mathrm{~m}^{3}$ bucket each (120 000 EUR).

- Organic fertiliser application: seven tractors of 2.0 drawbar category (250 000 EUR); seven machines for solid fertiliser spreading with a $6 \mathrm{t}$ capacity each (100 000 EUR).

Option 3. Processing of manure mixed with peat in a chamber bio-fermenter requires the following facilities and equipment:

- Bedding production: one concrete pad of $32 \times 16 \mathrm{~m}^{2}$ in area (18 280 EUR); six chamber-type bio-fermenters (214 280 EUR); one front-end loader with at least a $3 \mathrm{~m}^{3}$ bucket (60 000 EUR).

- Storing facilities for the bedding production components and ready products: one concrete pad with a shelter to store a three-day supply of peat of $30 \times 12 \mathrm{~m}^{2}$ in area (12 860 EUR); one concrete pad with a shelter to store the ready bedding of $60 \times 52 \mathrm{~m}^{2}$ in area (111 430 EUR).

- Transport facilities: three tractors of 2.0 drawbar category (107 140 EUR); three trailers with a 6 t capacity each (36 430 EUR); two front-end loaders with at least a $3 \mathrm{~m}^{3}$ bucket each (120 000 EUR).

- Organic fertiliser application: seven tractors of 2.0 drawbar category (250 000 EUR); seven machines for solid fertiliser spreading with a 6 t capacity each (100 000 EUR).

Comparative economic assessment of the considered cattle manure processing options to produce the bedding material is shown in Table 3.

In general, the solid-liquid manure separation significantly reduces the volume of processed waste. The relevant studies in EURpe, Asia and Russia have established that many agricultural producers consider this technology to be a fundamental one under agriculture intensification $[11,20$ 24]. Manure separation allows the use of more intensive, economically feasible and environmentally friendly technologies for manure utilization thereby increasing production profitability and safety [25]. Our study has confirmed this trend. 
Comparative economic assessment of the considered cattle manure processing options to produce the bedding material

\begin{tabular}{|l|c|c|c|}
\hline \multicolumn{1}{|c|}{ Indicator } & Option 1 & Option 2 & Option 3 \\
\hline Capital costs, EUR, including & 395914.3 & 1416571.4 & 1030428.6 \\
\hline$\bullet \quad$ Buildings and structures & 66428.6 & 117857.1 & 356857.1 \\
\hline$\bullet \quad$ Machines and equipment & 329485.7 & 1298714.3 & 673571.4 \\
\hline $\begin{array}{l}\text { Capital costs on a per unit basis, } \\
\text { EUR }^{-1}\end{array}$ & 99.6 & 356.3 & 259.2 \\
\hline $\begin{array}{l}\text { Operating costs, EUR·year } \\
\text { including }\end{array}$ & 151302.2 & 457304.7 & 376921.6 \\
\hline - Depreciation & 34277.1 & 132228.6 & 74494.3 \\
\hline$\bullet$ Maintenance and repairs & 30642.2 & 120780.4 & 62642.1 \\
\hline$\bullet$ Fuel & 46255.7 & 92960.0 & 133840.0 \\
\hline$\bullet$ Electricity & 15627.1 & 38585.7 & 27195.1 \\
\hline$\bullet \quad$ Wages & 24500 & 45500 & 51500 \\
\hline$\bullet \quad$ Peat & - & 27250 & 27250 \\
\hline $\begin{array}{l}\text { Operating costs on a per unit basis, } \\
\text { EUR per unit }\end{array}$ & 38.1 & 115.0 & 94.8 \\
\hline Labour inputs, man-hours· t $^{-1}$ & 0.45 & 0.84 & 0.94 \\
\hline Profit, EUR per unit & 159824.3 & -116714.3 & -21164.3 \\
\hline Pay-back period, year & 2.5 & - & - \\
\hline
\end{tabular}

\section{Conclusions}

1. Three manure processing options, which are used to produce bedding from manure, were considered for a dairy farm with the cow stock of 100 head: Option 1 - Aerobic fermentation of the solid manure fraction in a drum bio-fermenter; Option 2 - Aerobic fermentation of the manure-absorbing material (peat) mixture in a drum bio-fermenter; Option 3 - Aerobic fermentation of the manure-absorbing material (peat) mixture in a chamber bio-fermenter.

2. The annual production of bedding exceeds the farm's requirement of $40.2 \mathrm{t}$. The surplus can be either applied to the fields as a high-quality organic fertiliser or sold to other farms, thereby increasing the profitability of production. Following Option 1, $697 \mathrm{t}$ of bedding is produced annually. In Option 2 and Option 3, the annual bedding output is 6,740.6 and 7189.9 t, respectively. This sets a new task for the farm to search for potential consumers of the produced material since such amounts of processed manure cannot be used for fertilisation of the own agricultural land in the regulated agrotechnical time limits.

3. The study proved Option 1 (separation of manure into fractions, aerobic fermentation of the solid fraction in a drum bio-fermenter and long-term storing (maturing) of the liquid fraction in the manure storage) to be the most economically feasible manure utilisation. This option has the lowest capital (395 914 EUR) and operating costs (151302 EUR), the least labour inputs $\left(0.45\right.$ man-hours $\left.\cdot t^{-1}\right)$ and a short payback period of 2.4 years. Options 2 and 3 require significantly higher costs for implementation and operation that ultimately results in negative profitability.

4. The choice of a rational manure-processing technology allows the farmers to reduce costs and to receive an additional profit.

\section{References}

[1] Брюханов А.Ю. Обеспечение экологической безопасности животноводческих и птицеводческих предприятий: Наилучшие доступные технологии (How to provide environmental compatibility of livestock and poultry farms: Best Available Techniques). Saint Petersburg: IEEP, 2017. 296 p. (In Russian).

[2] Carroll E.J., Jasper D.E. Distribution of Enterobacteriaceae in recycled manure bedding on California dairies. Journal of Dairy Science, vol. 61 (10), 1978, pp. 1498-1508. 
[3] Leach K.A., Archer S.C., Breen J.E. etc. Recycling manure as cow bedding: Potential benefits and risks for UK dairy farms. The Veterinary Journal, vol. 206 (2), 2015, pp. 123-130.

[4] Lendelová J., Žitňák M., Bošanský M. etc. Testing of property changes in recycled bedding for dairy cows. Research in Agricultural Engineering, vol. 62 (SI), 2016, pp. 44-52.

[5] Chenyan L., Wei Q., Melse R.W. etc. Patterns of dairy manure management in China // International Journal of Agricultural and Biological Engineering, vol. 10 (3), 2017, pp. 227-236.

[6] Гордеев В.В., Хазанов В.Е., Миронов В.Н. и др. Молочная ферма с теплицей (Dairy farm with a greenhouse). Bulletin of the All-Russian Research Institute for Animal Husbandry Mechanisation: Вестник ВНИИМЖ, 2014, № 3 (15), pp. 184-187. (In Russian).

[7] Fournel S., Godbout S., Ruel P. etc. Production of recycled manure solids for bedding in Canadian dairy farms: I. Solid-liquid separation. Journal of Dairy Science, vol. 102 (2), 2019, pp. 1832-1846.

[8] Гирке 3. Коров на компост?! (Cows on compost?!). New Agriculture: Новое сельское хозяйство, 2014, No 2, pp.76-79. (In Russian).

[9] Брюханов А.Ю., Шалавина Е.В., Васильев Э.В. Методика укрупненной оценки суточного и годового выхода навоза/помета (Methodology of integrated estimation of daily and annual output of animal/poultry manure). Dairy Newsletter: Молочнохозяйственный вестник, 2014, No 1 (13), pp. 78-85. (In Russian).

[10] Уваров Р.А. Обоснование типоразмерного ряда барабанных биоферментаторов (Substantiation of type and size range of drum bio-fermenters). Technologies, Machines and Equipment for Mechanised Crop and Livestock Production: Технологии и технические средства механизированного производства продукции растениеводства и животноводства, 2018, No 94, pp. 143-150. (In Russian).

[11]Ковалёв Н.Г., Гриднев П.И., Гриднева Т.Т. Научное обеспечение развития экологически безопасных систем утилизации навоза (Scientific support for the development of environmentally safe systems of manure utilisation). Agricultural Science of the EUR-North-East: Аграрная наука Евро-Северо-Востока, 2016, No 1 (50), pp. 62-69. (In Russian).

[12] Uvarov R., Briukhanov A., Subbotin I. etc. Disinfection of solid fraction of cattle manure in drum-type bio-fermenter. Agronomy Research, vol. 15 (3), 2017, pp. 915-920.

[13]Fournel S., Godbout S., Ruel P. etc. Production of recycled manure solids for use as bedding in Canadian dairy farms: II. Composting methods. Journal of Dairy Science, vol. 102 (2), 2019, pp. 1847-1865.

[14] Уваров Р.А. Результаты исследования возможности рециклинга твердой фракции навоза КРС в подстилку (Research results of recyclability of solid cattle manure into bedding). Innovations in Agriculture: Инновации в сельском хозяйстве, 2015, № 5 (15), pp. 174-178. (In Russian).

[15] Межгосударственный стандарт ГОСТ 34393-2018 “Техника сельскохозяйственная. Методы экономической оценки" (Interstate Standard GOST 34393-2018. "Agricultural machinery. Methods of economic evaluation"). Moscow: Standartinrorm, 2018. 15 p. (In Russian).

[16]РД-АПК 1.10.15.02-17 Методические рекомендации по технологическому проектированию систем удаления и подготовки к использованию навоза и помёта (Management Directive for Agro-Industrial Complex 1.10.15.02-17. Recommended Practice for Engineering Designing of Systems for Animal and Poultry Manure Removal and Pre-application Treatment). Moscow: Rosinformagrotekh, 2017, 166 p. (In Russian).

[17]Ветеринарно-санитарными правилами подготовки к использованию в качестве органических удобрений навоза, помета и стоков при инфекционных и инвазионных болезнях животных и птицы (Veterinary and sanitary rules associated with the preparation of animal and poultry manure and wastewater, produced under conditions of infectious and invasive diseases of animals and poultry, to be used as organic fertilizers). Moscow: Yuridicheskaya Literatura Publishers, 1997, 19 p. (in Russian).

[18]Шалавина Е.В., Уваров Р.А., Васильев Э.В. и др. Результаты поисковых экспериментов биоферментации твердой фракции свиного навоза (Pilot study findings of bio-fermentation of the solid fraction of pig manure). Technologies, Machines and Equipment for Mechanised Crop and Livestock Production: Технологии и технические средства механизированного 
производства продукции растениеводства и животноводства, 2019, No 2 (99), pp. 326-334. (In Russian).

[19] Uvarov R., Briukhanov A., Shalavina E. Study results of mass and nutrient loss in technologies of different composting rate: case of bedding poultry manure. Proceedings of 15th International Scientific Conference "Engineering for Rural Development", May 25-27, 2016, Jelgava, Latvia, pp. 851-857.

[20] Kowalski Z., Makara A., Fijorek K. Changes in the properties of pig manure slurry. Acta Biochimica Polonica, vol. 60 (4), 2013, pp. 845-850.

[21] Hou Y., Velthof G.L., Case S.D.C. etc. Stakeholder perceptions of manure treatment technologies in Denmark, Italy, the Netherlands and Spain. Journal of Cleaner Production, vol. 172, 2018, pp. 1620-1630.

[22] Yuan Z., Pan X., Chen T. etc. Evaluating environmental impacts of pig slurry treatment technologies with a life-cycle perspective. Journal of Cleaner Production, vol. 188, 2018, pp. 840850.

[23] Bryukhanov A.Yu., Vasilev E.V., Volkov A.N. etc. Russia. Status of nutrient bookkeeping in the Baltic Sea countries. Dessau-Roßlau: Umweltbundesamt, 2015, pp. 33-35.

[24]Брюханов А.Ю., Васильев Э.В., Шалавина Е.В. и др. Методы решения экологических проблем в животноводстве и птицеводстве (Methods for solving environmental problems in animal and poultry farming). Agricultural Machinery and Technologies: Сельскохозяйственные машины и технологии, 2019, vol. 13, No 4, pp. 32-37. (In Russian).

[25] Makara A., Kowalski Z. Selection of pig manure management strategies: case study of Polish farms. Journal of Cleaner Production, vol. 172, 2018, pp. 187-195. 